\title{
ČLÁNKY
}

\section{Interpretace smluvních ujednání a jednostranných prohlášení stran v prostředí mezinárodního obchodu}

\author{
Interpretation of Contract`s Terms and Partie`s \\ Unilateral Declaration in International Trade Area
}

\author{
Naděžda Rozehnalová*
}

\begin{abstract}
Abstrakt
Interpretace smluvnich ujednáni má v mezinárodnim obchodnim styku zásadni význam. Roz̨dilnép predstavy stran o výkladu konkétnich probláseni íi ujednáni mohou komplikovat obchodní jednáni a vést až k soudnim sporim. Zajimavá je tato otážka v souvislosti s použitim Úmluvy OSN o smlowvách o mezinárodni koupi z̧boží, nebot' existence jednotnébo práva nezaručuje stejný výsledek roz̧odnutí. Naopak, možné rozdíly v interpretaci a následně $i$ aplikaci unifikované normy snižuji jeho význam. Clánek se zabývá analýzou pravidel interpretace jednáni stran obsažených v Úmluvě OSN o smlouvách o mezinárodni koupi zboži a uchopenim nékterých zvlástnich doložek či principu, kterými disponuje mezinárodni kontraktační praxe. Pozornost je rovněž vènována problematice vělenèní obchodnich podminek do smlouvy z.pobledu pravidel obsažených v úmluvě. Autorka dospivá k závèru, že interpretace smluvnich ujednání vykazuje $v$ mezinárodnim prostrèedí radu specifik. Zdirražnuje nutnost ad hoc př̌stupu založenébo na posouzení okolnosti konk rétního prĭpadu.
\end{abstract}

Klíčová slova

Interpretace smluvního ujednání; kontraktace; mezinárodni obchodni styk; pravidla interpretace; Úmluva OSN o smlouvách o mezinárodni koupi z̧boží; vélenèni obchodnich podminek.

\section{Abstract}

The contractual interpretation is of fundamental importance in the international trade relations. Different notions of parties about the interpretation of particular statements or agreements may complicate business transactions and even lead to litigation. This question is interesting in connection with the application of the UN Convention on Contracts for the International Sale of Goods, because the existence of the unified law does not guarantee the same result of a decision. On the contrary, possible differences in interpretation and consequently in the application of the unified rules diminish its importance. The article deals in particular with the analysis of the rules of interpretation and with the treatment of some special clauses or principles, which are available in the international contract practice. Special attention is paid to the issue

\footnotetext{
Prof. JUDr. Naděžda Rozehnalová, CSc., Katedra mezinárodního a evropského práva, Právnická fakulta, Masarykova univerzita, Brno / Department of International and European Law, Faculty of Law, Masaryk University, Brno, Czech Republic / E-mail: 1860@muni.cz / ORCID: 0000-0002-8907-2718
} 
of the incorporation of standard terms and conditions into the contract. The author concludes that the contractual interpretation shows a number of specifics in the international context and emphasizes the need for an ad hoc approach based on the assessment of the circumstances of a particular case.

\section{Keywords}

Contracting; Contractual Interpretation; Incorporation of Standard Terms and Conditions; International Trade Relations; Rules of Interpretation; UN Convention on Contracts for the International Sale of Goods.

\section{Úvod}

Interpretace prohlášení či jednání strany a následně uzavřených smluv patří k otázkám, které mohou komplikovat mezinárodní obchodní jednání či průběh a výsledek plnění uzavřené smlouvy. Odchylné představy jednajících partnerů o významu jednání či prohlášení strany či o smyslu doložek dohodnutých ve smlouvě a následná rozdílná reakce či chování mohou vést k soudním sporům - sporům z nedorozumění či neporozumění. Představy o významu jednání, prohlášení či ujednání stran ovlivňuje v mezinárodním prostředí řada faktorů. Zkušenost hovoří o determinaci domácím - národním - prostředím, odkud smluvní partneři pocházejí. Dále jsou to také rozdílná východiska pro uchopení interpretace $\mathrm{v}$ jednotlivých právních oblastech, ${ }^{1}$ vliv zvyklostí dodržovaných v dané oblasti či u obchodované komodity, a v neposlední řadě jazyk jednání či smlouvy. Mohou-li být výrazy a slova rozdílně pochopeny v národním prostředí, je tomu o to více v prostředí mezinárodním, kde pro jednu či obě strany může být jazyk smlouvy či jednání jazykem cizím. Navíc za situace, kdy se jazyk právní, který je užíván v oblasti mezinárodního obchodu, v některých ohledech liší od jazyka obecného.

Výše uvedené, a možná i další okolnosti mohou napomoci vzniku interpretačních problémů. A to i tam, kde by interpretace smluvních ujednání či prohlášení strany nečinila ve vnitrostátním prostředí žádné výrazné nároky na intelektuální výkon a nebyla by ani vnímána jako sofistikovaný proces interpretace. ${ }^{2}$

1 Na mysli máme uchopení východisek pro interpretaci a současně základní dichotomii v této otázce subjektivní a objektivní interpretaci. Onen různý akcent na hledání vůle stran na jedné straně, spíše charakteristický pro oblast kontinentálního práva, či naopak akcent na druhou pozici objektivizující zaujetí stanoviska k výkladu a charakteristický spíše pro oblast common law, doprovází právo od dob římského práva a line se i jednotlivými právními úpravami, at' již národními či mezinárodními. Blíže i s odkazy na další literaturu: CSZERNE, Peter. Policy Consideration in Contract Interpretation: the contra proferentem Rule from a Comparative Law and Economics Perspective. Working paper [online]. 2007, č. 5 [cit. 4. 4. 2018]. Dostupné z: http://works.bepress.com/peter_cserne/28/

2 K problematice interpretace ve vnitrostátním prostředí u obchodních podmínek viz: KOTÁSEK, Josef. Interpretace obchodních podmínek. In: BEJČEK, Josef, Josef KOTÁSEK, Monika PŘÍLAZSKÁ a kol. Obchodní podmínky. 1. vyd. Brno: Masarykova univerzita, Právnická fakulta, 2016, 304 s., s. 137 a násl. ISBN 978-80-210-8424-7. Zejména lze poukázat na metodologické poznámky k problematice složitosti či naopak jednoduchosti výkladu. Nelze jinak než souhlasit. Je-li něco jednoduché, resp. existuje beze sporu jednotný výklad užitého pojmu či jednání, neznamená to, že se nejedná o výklad. 
K nalezení východisek a zásad interpretace jednání, prohlášení či ujednání stran lze $\mathrm{v}$ mezinárodním prostředí přistoupit vícero způsoby. V prvé řadě je to nalezení rozhodného národního práva tam, kde neexistuje jednotné unifikované hmotné právo. Při tomto procesu využíváme mezinárodní právo soukromé a v našem prostředí tzv. kolizní metodu disponující kolizními normami. ${ }^{3}$ Českému právnímu prostředí dominuje Nařízení o právu rozhodném pro smlouvy a jeho ustanovení článku 12, které určuje rozsah obligačního statutu. ${ }^{4}$ Do něj spadá i otázka interpretace řídící se legis causae smlouvy (právem rozhodným pro smlouvu). K určení rozhodného práva se v základní poloze využívá volba práva (článek 3), či v případě její neexistence či neplatnosti náhradní hraniční určovatel (článek 4). Zvláštní úprava existuje pro smlouvy spotřebitelské, pojišt'ovací, přepravní a individuální pracovní (články 5, 6, 7 a 8). Napojení na národní právo představuje nejméně komfortní a nejméně vhodný způsob regulace - př́pady překračující hranice státu podléhají národní regulaci. Nicméně proces hmotněprávní unifikace se $\mathrm{v}$ podstatě zastavil ${ }^{5}$ a využití národního práva, určeného na základě pravidel mezinárodního právo soukromého, představuje pravděpodobně způsob nejčastější. Upozornit je nutné rovněž na další možný rozdíl $\mathrm{v}$ aplikaci. A to tam, kde bude spor řešen před mezinárodními rozhodci, a k určení rozhodného práva se využívá jiných cest oproti řízení před soudy obecnými. ${ }^{6}$

V omezených prrípadech je možné využít také metodu přímou a existující jednotné normy, které jsou zpravidla obsaženy v mezinárodní úmluvě. K této otázce se vrátíme pohledem Úmluvy OSN o smlouvách o mezinárodní koupi zboží. Upozornit je však třeba, že ani při využití jednotného hmotného práva nemusíme vždy dojít ke stejným výsledkům. Existence jednotného práva neznamená ještě existenci stejného rozhodovacího výsledku. Mezery v úpravě, možné rozdíly v interpretaci a následně v aplikaci snižují hodnotu unifikace.

3 V české literatuře ke kolizní metodě a jejímu uchopení: KUČERA, Zdeněk, Monika PAUKNEROVÁ, Květoslav RŮŽIČKA a kol. Mezinárodni právo soukromé. 8. vyd. Plzeň: Vydavatelství a nakladatelství Aleš Čeněk, s. r. o. 2015, 430 s., s. 99-195. ISBN 978-80-7380-550-0; ROZEHNALOVÁ, Naděžda, Jiří VALDHANS, Klára DRLIČKOVÁ a Tereza KYSELOVSKÁ. Úvod do mezinárodního práva soukromébo. 1. vyd. Praha: Wolters Kluwer, 2017, 258 s. ISBN 978-80-7552-699-1.

4 Nařízení Evropského parlamentu a Rady (ES) č. 593/2008 ze dne 17. června 2008 o právu rozhodném pro smluvní závazkové vztahy (Řim I). Viz blíže v české literatuře: ROZEHNALOVÁ, Naděžda, VALDHANS, Jiří, DRLIČKOVÁ, Klára a Tereza KYSELOVSKÁ. Męinárodní právo soukromé v Evropské unii. 1. vyd. Praha: Wolters Kluwer, 2013, 448 s., s. 57-141. ISBN 978-80-7478-016-5; PAUKNEROVÁ, Monika. Evropské mezinárodni právo soukromé. 2. vyd. Praha: C. H. Beck, 2013, 540 s., s. 151-180. ISBN 97880-7400-034-8; BĚLOHLÁVEK, Alexander J. Ř́mská úmluva a Nařizení Řím I: komentárv širších souvislostech evropského a mezinárodního práva soukromého. 1. vyd. Praha: C. H. Beck, 2009, 2894 s.; BŘÍZA, Petr. Volba práva a volba soudu v mezinárodním obchodě. 1. vyd. Praha: C. H. Beck, 2012, 300 s. ISBN 978-80-7400-176-5; ROZEHNALOVÁ, Naděžda. Závazky ze smluv a jejich právni rě̌im (se zuláštním žretelem na evropskou kolizni úpravu). 1. vyd. Brno: Masarykova univerzita, 2010, 273 s. ISBN 978-80-210-5240-6.

5 Toto tvrzení lze dokladovat na činnosti komise UNCITRAL. V posledních desetiletích přešla od mezinárodních úmluv k vzorovým úmluvám a návodům. Viz přehled dostupný z: http://www.uncitral.org/ uncitral/en/uncitral_texts.html [cit. 4.4.2018].

$6 \mathrm{~K}$ rozdílům $\mathrm{v}$ určení rozhodného práva před mezinárodními rozhodci viz $\mathrm{v}$ české literatuře: ROZEHNALOVÁ, Naděžda. Roz̧hodči ř́zení v mezinárodním a vnitrostátním obchodním styku. 3. vyd. Praha: Wolters Kluwer ČR, 2013, 400 s., s. 233-287. ISBN 978-80-7478-004-2. 
Vedle řešení legislativních, zakotvujících interpretační kánony, se objevují aktivity nestátních profesních organizací vydávajících doporučení, vysvětlení či návodné jednotné interpretace pojmů či termínů. Nejznámějšími a nejvyužívanějšími pravidly jsou INCOTERMS, které se snaží o překlenutí různé interpretace pojmů či zvyklostí v oblasti mezinárodních dodávek zboží, kde se nelze spoléhat na obvyklý význam termínu tak, jak je vnímán v obecném jazyce. Vedle INCOTERMS existují i další prostředky zvyklostního původu či vytvořené mimo legislativní činnost státu a napomáhající uchopení smyslu jednání, prohlášení či ujednání ve smlouvě. Vlastní dopad prostředků vytvořených v mezinárodní obchodní praxi může být zprostředkovaný přes národní právo či mezinárodní jednotnou normu. Nicméně za určitých podmínek mohou být pravidla nestátního původu využita př́mo. Bez oné cesty přes národní či unifikované hmotné právo. Na mysli máme ř́izení před mezinárodními rozhodci $\mathrm{v}$ prrípadech, kdy je využito široké autonomie vưle stran a lze vyloučit aplikaci hmotného práva konkrétního státu. Př́padně může jít rozhodování dle ekvity, amiable compositeur či zásad spravedlnosti. Nebo o situaci, kdy pravidla rozhodčí instituce umožňují přednostní aplikaci mezinárodních zvyklostí. Právě akcent na mezinárodní obchodní praxi a mezinárodní prostředí (ostatně vyplývá i z článku 9 Úmluvy OSN o smlouvách o mezinárodní koupi zboží upravujícího mezinárodní obchodní zvyklosti, které mají často interpretační povahu) nám uvádí i pozici či pozice stran - mezinárodních obchodníků. Je to právě toto prostředí, které může zásadně pozměnit ta pravidla, se kterými „přicházíme“ z vnitrostátního práva a která nás často ovlivňují.

Jaký je cíl článku? Po úvodním přehledu toho, jaká existují pravidla interpretace v Úmluvě OSN o smlouvách o mezinárodní koupi zboží, kde je hledat, jak s nimi pracovat, se budeme věnovat uchopení některých zvláštních smluvních doložek, kterými disponuje mezinárodní kontraktační praxe a se kterými, byt' jsou ovlivněny či vznikly v prostředí národním, se běžně setkáváme $\mathrm{v}$ prostředí mezinárodním. Jde o doložky, které mohu mít vliv právě na interpretaci jednání, prohlášení strany či ujednání stran. Rovněž vyhodnotíme interpretační principy, které se objevují na národní a mezinárodní úrovni pro interpretaci jednání stran, nicméně v námi sledované úpravě nejsou př́mo uvedeny. Centrem článku je uvedení této problematiky v Úmluvě OSN o smlouvách o mezinárodní koupi zboží. ${ }^{8}$

7 FONTAINE Marcel a Filip De LY. Drafting International Contracts. An Analysis of Contract Clauses. Boston-Leiden: Martinus Nijhoff Publishers. 2. vyd. 2009, 653 s., s. 106-107, s. 113. ISBN 978-9004176799; K rozhodnému právu před rozhodci v české literatuře: ROZEHNALOVÁ, Naděžda. Rozhodčí řžnenív mezi národním a vnitrostátním obchodním styku. 3. vyd. Praha: Wolters Kluwer, 2013, 400 s., s. 233-287. ISBN 97880-7478-004-2; ROZEHNALOVÁ, Naděžda. Právo rozhodné v řízení před mezinárodními rozhodci (tendence $\mathrm{v}$ oblasti závazkového práva $\mathrm{s}$ přihlédnutím $\mathrm{k}$ úpravám $\mathrm{v}$ některých evropských zemích). Právník, Praha: Ústav státu a práva ČSAV, 2000, roč. 138, č. 11, s. 1066-1086. BĚLOHLÁVEK, Alexander J. Právo použitelné na řízení před rozhodci. Právo a podnikání, Praha: Orac, 2005, roč. 14, č. 11, s. 2-9.

8 Úmluva OSN o smlouvách o mezinárodní koupi zboží, sdělení FMZV č. 160/1991 Sb. (text viz u depozitáře www.uncitral.org). Úmluva vstoupila $\mathrm{v}$ platnost na základě svého článku 99 odst. 1 dnem 1. ledna 1988. Pro Českou a Slovenskou Federativní Republiku vstoupila v platnost v souladu se svým článkem 99 odst. 2 dnem 1. dubna 1991. Na uvedených www stránkách lze nalézt také výčet smluvních států. 
Pozornost budeme věnovat také problematice uchopení a včlenění obchodních podmínek do smlouvy pohledem interpretace jednání stran a článku 8 úmluvy.

Na úvod si připomeňme výstižná a nestárnoucí slova E. Allan Farnswortha, který se ve své stati zabývá nikoli pohledem zákonodárce, soudce či rozhodce, tedy pohledem následným, ale pohledem osoby navrhující smlouvu v mezinárodním prostředí. A těmi slovy lze i vlastně uvést tento článek: „For the draftsman the question is not whether a particular clause is or is not enforceable under the law of a particular jurisdiction; the question is rather whether the clause has a sufficient chance of being held enforceable under the law of some jurisdiction whose law might turn out to be the governing law to merit its inclusion in the contract." "9

Ano, práce s předpokladem platnosti je to, kde se často $\mathrm{v}$ mezinárodním obchodním styku, a to nejen při uzavírání smluv, pohybujeme. Je třeba vnímat riziko rozdílné interpretace a bud' se jej snažit minimalizovat a řídit, nebo jej vnímat, žít s ním a počítat s ním v prŕpadě soudního sporu. Znát jej je tak třeba ve všech prrípadech.

\section{1 Úmluva OSN o smlouvách o mezinárodní koupi zboží}

Úmluva OSN o smlouvách o mezinárodní koupi zboží (dále jen Vídeňská úmluva či úmluva) představuje základní unifikovanou úpravu mezinárodní koupě zboží realizovanou mezi obchodníky. Díky počtu smluvních stran jde o významný dokument s potenciálem zásahu zajímavého objemu mezinárodních kupních smluv. Úmluva obsahuje výslovnou regulaci interpretace prohlášení či jiného chování strany při zohlednění prostředí, ve kterém se tato projevuje - mezinárodním obchodě. Samotná úprava problematiky v článku 8 vyvolala řadu otázek jak pro svou formulaci, tak i pokud jde o aplikaci samotnou. Připomenout je nutné, že právě ve snaze o jednotnou interpretaci a aplikaci úmluvy (viz článek 7) vznikla řada aktivit snažících se napomoci jednotnému výkladu. Základní cestou je zprostředkování rozhodování národních soudů a rozhodčích senátů. ${ }^{10}$ Zmínit je vhodné, právě pro význam pro otázku interpretace, také neformální akademickou aktivitu - tvorbu tzv. opinions. ${ }^{11}$ Jimi, resp. pravidly v nich uvedenými, se budeme rovněž zabývat. Vedle vlastní analýzy a odborných textů to jsou i tyto sjednocené názory významných odborníků z oblasti mezinárodního obchodu, které napomáhají přiblížit význam textu.

9 FARNSWORTH, Edgar Allan. The Interpretation of International Contracts and the Use of Preambles. Revue de droit des affaires internationales / International Business Law Journal, London: Sweet \& Maxwell, 2002, roč. 3, č. 3-4, s. 271-279, s. 271.

10 Z nejznámějších internetových portálů lze doporučit: www.uncitral.org vedený mezinárodní organizací UNCITRAL a uvádějící v rámci databáze CLOUT rozhodnutí národních soudů; www.unidroit.org vedený mezinárodní organizací UNIDROIT a uvádějící v rámci databáze UNILEX rozhodnutí národních soudů; databázi vedenou Institutem mezinárodního práv (Institute of International Commercial Law) při Pace Law School (Pace University). Dostupné z: https://cisgw3.law.pace.edu/

11 Jedná se o stanoviska prestižních právníků, která analyzují různé aspekty Vídeňské úmluvy. Nejsou závazná, nicméně používají velké neformální vážnosti. Věnují se řadě otázek, které jsou interpretačně problémové [online]. [cit. 10.4.2018]. Dostupné z: http://www.cisgac.com 
Základní otázkou, na kterou v historii přijímání článku 8 neexistovaly jednotné názory a kterou je nutné uvést na úvod, je jeho rozsah. Tedy na jaké otázky článek dopadá. Problémy s vymezením rozsahu lze uvést následovně: Dopadá toto ustanovení jen na utvárení smlouvy, nebo i na probláseni a chováni strany č stran realizovaných po vzniku této smlouvy? Dopadá jen a výlučnè na chováni a problášeni strany jako na jednostranné právni úkony vážici se ke smlouvě véetné jeji formace, nebo zahrnuje i interpretaci smluvnich ustanoveni? Otázky se objevují jak vzhledem k historii přijímání tohoto článku, tak i vzhledem k jeho jazykové podobě a formulaci pravidel v článku uvedených. Sám článek 8 totiž pracuje jen s prohlášením či chováním jednotlivých stran. Nepracuje výslovně, přestože se jedná o obecné ustanovení, se společným obsahem, tedy smlouvou a jejími ustanoveními tak, jak je tomu např́íklad u Zásad mezinárodních smluv UNIDROIT. ${ }^{12}$

Na obě uvedené otázky je možné odpovědět kladně. Jak vyplývá z materiálů přijatých v rámci prací UNCITRAL, ${ }^{13}$ tak i pokud jde o názory v odborné literatuře, ${ }^{14}$ dopadá uvedené ustanovení nejen na jednostranná prohlášení či chování stran při uzavírání smlouvy, ale i na interpretaci významu jednotlivých smluvních ustanovení, na význam prohlášení či chování stran v průběhu plnění, resp. na jejich prohlášení a chování ve vazbě na zánik smlouvy. Podobné dokazují i rozhodnutí soudů. ${ }^{15}$ Smlouva je uchopena jako výsledný produkt dvou jednostranných prohlášení či chování se stran. ${ }^{16} \mathrm{Z}$ tohoto pohledu není nutné mít pochybnosti o rozsahu dopadu článku 8.

Není rovněž zřetelné, zda článek 8 dopadá na otázky vyloučené z dosahu Vídeňské úmluvy - tzn. vyloučené v článcích 4 a 5 úmluvou samotnou, nebo vyloučené dohodou stran umožněnou článkem 6 . Jednotné názory neexistují ani v literatuře, ani v rozhodovací praxi. Pokud jde o mezery úpravy jako je prohlášení započtení, vyjádření výhrady

12 UNIDROIT. Principles of International Commercial Contracts 2016 (čtvrtá verze, předcházející verze jsou z let 1994, 2004, 2010) [cit. 1.1.2018]. V článku 4 jsou obsaženy zásady interpretace smlouvy mezi stranami. Dostupné z: http://www.unidroit.org

13 Documents of the Conference and Summary Records of the Plenary Meetings and of the Meetings of the Main Committee. United Nations Conference on Contracts for the International Sale of Goods, Vienna, 10 March-II April 1980, Official Records, s. 18. Dále jen Documents.

14 FERRARI, Franco, Harry FLECHTNER a Ronald A. BRAND (eds.). The Draft UNCITRAL Digest and Beyond. 1. vyd. Munich: Sellier. European Law Publishers, 2004, 874 s., s. 173-174. ISBN 3-935808-143; SCHWENZER, Ingeborg, Christiana FOUNTOULAKIS a Mariel DIMSEY. International Sales Law. 1. vyd. Oxford, Portland, Oregon: Hart Publishing, 2012, 507 s., s. 61, s. 56-57. ISBN 1849463026; SCHLECHTRIEM, Peter a Petra BUTLER. UN Law on International Sales: The UN Convention on the International Sale of Goods. Berlin, Heidelberg: Springer Verlag. 2009, 352 s., s. 56. ISBN 9783540253143.

15 Digest of Case Law on the United Nations Convention on Contracts for the International Sale of Goods. [online]. Wien: UNCITRAL, 2016, s. 54 [cit. 4.2.2018]. Dostupné z: http://www.uncitral.org/pdf/english/ clout/CISG_Digest_2016.pdf

16 Documents, op. cit., s. 18. Stejně také Guide CISG art. 8. Secretariat Commentary [online]. [cit. 1.2. 2018]. Dostupné z: https://cisgw3.law.pace.edu/cisg/text/secomm/secomm-08.html. Stejně literatura viz např́lklad: HUBER, Peter a Alastair MULLIS. The CISG: A New Textbook for Students and Practitioners. 1. vyd. Munich: Sellier. European Law Publishers. 2007, 408 s., s. 12. ISBN 978-3-86653-020-1. 
vlastnického práva, určení výše úroků či určení smluvní pokuty, objevují se názory o využití článku 8 úmluvy pro interpretaci úmyslu. ${ }^{17}$ Nikoli využití národního práva. Naopak se lze setkat i s názory zastávající pozici plného vyloučení dopadu článku $8 \mathrm{v}$ př́padech výše uvedených mezer. $\mathrm{V}$ takovém př́padě by se použilo národní právo. ${ }^{18}$ Obě cesty jsou dle našeho názoru možné a vykazují jak výhody, tak nedostatky. Využití článku 8 pro interpretaci úmyslu přispívá k jednotnému interpretačnímu uchopení konkrétní posuzované smlouvy. Přispívá k její právní integritě. Naopak vyloučení aplikace článku 8 a plné využití dopadu národního práva na vyloučené otázky akcentuje integritu při aplikaci národního práva vykrývajícího mezery v úpravě. Osobně se přikláníme k využití prvé varianty. Za nesporné jej považujeme u vyjádření vưle dle článku 6 - tedy vyloučení výslovné či nevýslovné některého z ustanovení úmluvy. Nicméně i pro další př́ípady vyjádření úmyslu jej preferujeme. Akcentujeme tím trend, který se projevuje i v jiných otázkách a který upřednostňuje maximální využití unifikovaného textu před návratem k národnímu právu. Tento přístup odpovídá rovněž článku 7, který klade pro interpretaci textu úmluvy důraz na mezinárodní povahu dokumentu. Jde sice o pravidlo pro interpretaci textu úmluvy, nicméně mu nelze upř́it vliv i na námi zkoumanou otázku.

Pro interpretaci jednání obsahuje Vídeňská úmluva v článku 8 tři základní pravidla obsahující i určení jejich aplikační hierarchie: a) interpretaci dle úmyslu, pokud byl tento znám druhé straně; nebo b) interpretaci dle úmyslu, pokud tento nemohl být druhé straně neznám; nebo c) interpretaci dle významu, který by prohlášením a jednáním přikládala za týchž okolností rozumná osoba v tomtéž postavení jako druhá strana. Čtvrté pravidlo, které je obsaženo v uvedeném článku, uvádí okolnosti, které mají být při interpretaci vzaty do úvahy.

Základním pravidlem, resp. přesněji výchozím pravidlem, které využívá odstavec prvý, je úmysl strany, která realizovala jednání, a který je znám straně druhé, nebo jí nemohl být neznám. Zde uvedené pravidlo obsahuje dvě varianty situací, v nichž může být využito: případ, kdy existuje skutečný (či lze říci i zřetelný) úmysl známý druhé straně a situaci, kdy opět existuje skutečný úmysl, který nemohl být druhé straně neznám.

Využití tzv. subjektivního př́stupu k interpretaci, kdy je hledán skutečný úmysl jedné ze stran (prvá strana) a podmínkou pro jeho zohlednění je to, že tento byl druhé straně znám či nemohl být neznám, je základním východiskem pro využití interpretačního pravidla dle prvého odstavce. Důkazně je zatížena strana prvá. ${ }^{19}$ Vzhledem k tomu, že článek 8 spočívá na konceptu interpretace jednostranných aktů stran, není možné přímo

17 SCHLECHTRIEM, Peter. Internationales UN-Kaufrecht. 3. vyd. Tübingen: Mohr Siebeck, 2007, 283 s., s. 53. ISBN 978-3161486463.

18 SCHWENZER, Ingeborg, Christiana FOUNTOULAKIS a Mariel DIMSEY. International Sales Law. 1. vyd. Oxford, Portland, Oregon: Hart Publishing, 2012, 507 s., s. 60. ISBN 1849463026.

19 MAZOTTA, Francesco G. General Provisions. In: ANDERSSEN BAASCH, Camilla, Francesco MAZZOTA a Bruno ZELLER. Practitioner's Guide to the CISG. 1. vyd. New York: Juris Publishing, 2010, 1218 s., s. 95. ISBN 9781933833378. 
vyvodit společný úmysl jako prostředek interpretace. ${ }^{20}$ Naopak, východiskem je zkoumání úmyslu strany, nikoli společného úmyslu stran. Nicméně tam, kde by se nejednalo o pouhé jednostranné akty, ale půjde např́iklad o smluvní ustanovení, úmysl je, resp. by měl být, do aktu vepsán a je identifikovatelný. A nerozporován druhou stranou. V př́padech, kdy existují spory o význam smluvních ustanovení, má odstavec prvý, obsahující pravidlo subjektivního úmyslu jednající osoby, omezené využití.

Odstavec prvý využívá dvou podob úmyslu - ten, který byl druhé straně znám, a ten, který nemohl být druhé straně neznám. Musí se jednat o úmysl skutečný, ${ }^{21}$ nikoli úmysl hypotetický tak, jak jej známe z některých národních úprav. Úmysl musí být určitým způsobem vyjádřen, nemůže být skryt. V této souvislosti je zdůrazněna zásada ,falsa demonstratio non nocet".22 Tedy pokud obě strany míní totéž, byt' skutečnost označily chybně, jejich společné porozumění převažuje nad porozuměním, byt' objektivním, osoby třetí, stojící mimo smlouvu. Ve druhém prrípadě - úmysl nemohl být druhé straně neznám jsou literaturou zdůrazněny dva momenty. Jednak je uvedeno zavedení určitého objektivizačního filtru do jinak subjektivního testu, ${ }^{23}$ jednak je termín „,nemohl být neznám“ dán na roveň hrubé nedbalosti. ${ }^{24}$ Problém uváděný u subjektivního konceptu a důvod jeho menšího využití v rámci sporů je otázka důkazu a unesení toho, že strana úmysl znala, nebo jí nemohl být neznám. Rovněž, jak jsme již uvedli, interpretace textů vzniklých mimo dosah stran, jako jsou všeobecné obchodní podmínky, vytváří jinou pozici. Jak uvádějí i Digesta 2012, měly by se soudy nejprve pokusit určit význam prohlášení

20 Documents, op. cit., s. 14; rovněž také Guide CISG Art. 8. Secretariat Commentary [online]. [cit. 3. 5. 2014]. Dostupné z: https://cisgw3.law.pace.edu/cisg/text/secomm/secomm-08.html

21 FERRARI, Franco. Interpretation of statements. Article 8. In: FERRARI, Franco, Harry FLECHTNER a Ronald A. BRAND (eds.). The Draft UNCITRAL Digest and Beyond. 1. vyd. Munich: Sellier. European Law Publishers, 2004, 874 s., s. 176-177. ISBN 3-935808-14-3. Zajímavé je z určitého pohledu také rozhodnutí uváděné v Digestech 2012 v odkaze 20 (Audencia Provincial de Navarra, seccion 3a, Španělsko, 27. prosince 2007). Soud výslovně uvedl, že při použití subjektivních interpretačních pravidel článek 8 odst. 1 vybízí ke zkoumání skutečného úmyslu, nikoli k hluboké psychologické analýze. Tento vhodně vyjádřený pragmatismus představuje rovněž to, co uvádíme i dále - přechod od odstavce prvého k odstavci druhému. KOMISE OSN PRO MEZINÁRODNÍ OBCHODNÍ PRÁVO (UNCITRAL). Výbèr z. rozhodovaci praxe k Úmluvě OSN o smlouvách o mez̧inárodni koupi z̧boži 2012. Překlad Soňa Reimannová, odborná revize překladu Zbyšek Kordač a Vít Lederer. 1. vyd. Praha: Wolters Kluwer ČR, 2018, 860 s., s. 87. ISBN 978-80-7552-931-2. Dále jen Digesta 2012 - překlad.

22 HUBER, Peter a Alastair MULLIS. The CISG: A New Textbook for Students and Practitioners. 1. vyd. Sellier. European Law Publishers. 2007, 408 s., s. 12. ISBN 978-3-86653-020-1; FERRARI, Franco. Interpretation of statements. Article 8. In: FERRARI, Franco, Harry FLECHTNER a Ronald A. BRAND (eds.). The Draft UNCITRAL Digest and Beyond. 1. vyd. Munich: Sellier. European Law Publishers, 2004, 874 s., s. 177. ISBN 3-935808-14-3.

23 HUBER, Peter a Alastair, MULLIS. The CISG: A New Textbook for Students and Practitioners. 1. vyd. Sellier. European Law Publishers. 2007, 408 s., s. 12. ISBN 978-3-86653-020-1.

24 HUBER, Peter. Some introductory remarks on the CISG. Internationales Handelsrecht. Munich: Sellier, European Law Publishers. 2006, roč. 18, č. 6, s. 236; HUBER, Peter a Alastair MULLIS. The CISG: A New Textbook for Students and Practitioners. Sellier. European Law Publishers. 2007, 408 s., s. 12. ISBN 978-3-86653-020-1. 
nebo chování strany tím, že budou zkoumat její skutečný úmysl. Nicméně ve většině případů nepůjde o situaci, kdy jej strany dají najevo, a spíše se potom použije odstavec $2 .{ }^{25}$

Odstavec druhý - objektivní test. Nelze-li využít úmysl skutečný, bude v souladu s odstavcem druhým využito objektivních kritérií. Namísto vyhledání skutečného významu bude hledán význam ,předpokládaný“ či „,normativni““. ${ }^{26}$ Tím se rozumí takový postup, kdy je chování či prohlášení strany vykládáno dle významu, který by mu přikládala za týchž okolností rozumná osoba v tomtéž postavení jako druhá strana. Parametry objektivního testu jsou v úmluvě dány pozicí „rozumné osoby“, která je v „tomtéž postavení jako druhá strana" a význam príkládá za „stejných okolností".

Odstavec 3. Tento odstavec vymezuje pro předcházející pravidla interpretace okolnosti, které mají být zohledněny při interpretaci chování či vyjádření strany. V souladu s ním má být vzat žretel na všechny rozhodné okolnosti. Odstavec obsahuje demonstrativní výčet takových okolností, nikoli výčet taxativní. ${ }^{27}$ Jde např́iklad o jednání o smlouvě, praxi, kterou strany mezi sebou zavedly, zvyklosti a následné chování stran.

Samostatnou problematiku představují obchodní podmínky, které byly vypracovány mezinárodní organizací, obchodním svazem apod. Tedy přijaty nikoli jako zákon či mezinárodní úmluva, ${ }^{28}$ nýbrž přijaty nestátní organizací, a konkrétní strany, které je navrhly a využívají je, se neúčastnily jejich zpracování. ${ }^{29} \mathrm{~K}$ této otázce a k otázce týkající se toho, zda se staly obchodní podmínky součástí smlouvy, se vrátíme v dalším textu.

\section{Pravidlo contra proferentem pohledem interpretace dle Vídeňské úmluvy}

Pravidlo contra proferentem, resp. in dubio contra proferentem ${ }^{30}$ představuje vděčné téma pro diskuse a to jak pokud jde o účel, tak i povahu promítnutí či aplikační pořadí a sílu vưči jinak

25 Digesta 2012 překlad, s. 87; rovněž odkaz na rozhodčí nález č. 8324, Court of Arbitration of the International Chamber of Commerce, 1995, převzato z databáze UNILEX [online]. [cit. 2. 3. 2018]. Dostupné z: http://www.unilex.info/. Podobně také CLOUT. Rozhodnutí c. 222, US Court of Appeals (11th Circuit), Spojené státy americké, 29. červen 1998 [online]. [cit. 3.2.2018]. Dostupné z: http://www.uncitral.org/uncitral/en/case_law.html

26 UNCITRAL. Digest of Case L aw on the United Nations Convention on Contracts for the International Sale of Goods. 2016 Edition [online]. S. 55 [cit. 2.1.2018]. Dostupné z: http://www.uncitral.org/pdf/english/clout/CISG_Digest_2016.pdf

27 MAZOT'TA, Francesco G. General Provisions. In: ANDERSSEN BAASCH, Camilla, Francesco MAZZOTA a Bruno ZELLER. Practitioner's Guide to the CISG. 1. vyd. New York: Juris Publishing, 2010, 1218 s., s. 95. ISBN 9781933833378.

28 Cestou mezinárodní úmluvy byly v minulosti přijaty např́iklad Všeobecné podmínky pro dodávky zboží mezi organizacemi členských států Rady vzájemné hospodářské pomoci (VDP RVHP 1968/1975).

29 Obecně k problematice obchodních podmínek a formulářových smluv v mezinárodním obchodě viz: ROZEHNALOVÁ, Naděžda. Standardizované formy uz̨avíráni smluv v meżinárodním obchodním styku. 1. vyd. Brno: Masarykova univerzita, Právnická fakulta, 1991, 189 s. ISBN 55-956-91.

30 Jedná se o pravidlo, které stanoví, že tam, kde je výklad termínu nejasný či dvojznačný, nese riziko této nejasnosti či dvojznačnosti ta strana, která jej navrhla. Blíže ke genezi tohoto pravidla viz: BALDUS, Christian. Regelhafte Vertragsauslegung nach Parteirollen im klassischen römischen Recht und in der modernen Völkerrechtswissenschaft: zur Rezeptionsfähigkeit römischen Rechtsdenkens. Frankfurt am Main, Berlin: Verlag Lang. 1998, 488 s. ISBN 3631342969. 
„standardním“ výkladovým pravidlům. ${ }^{31}$ Je známo řadě národních právních rádů, využívá ho i česká vnitrostátní úprava. ${ }^{32}$ Č́stí literatury věnované Vídeňské úmluvě je uváděno jako obecně známé a využívané pravidlo i v mezinárodním prostředí. Zatímco na národních úrovních je bud' výslovně či judikaturou připuštěno a je zpravidla výslovně uvedena aplikační pozice vưči základním normativně upraveným interpretačním pravidlům, má uchopení pravidla v rámci Vídeňské úmluvy daleko do jednoznačnosti. Výslovná úprava neexistuje, literatura se názorově v řadě aspektů, včetně důvodů proč ano, liší. Ona poměrně nevelká zmapovaná část judikatury se spíše přiklání k jejímu použití, resp. jej využívá. ${ }^{33}$ A vlastně ani hlasů uvádějících zásadní „ne“ mnoho není. Důvody „pro“ jsou nicméně mnohdy obtížně identifikovatelné. Vedle těch, které přímo vycházejî z úmluvy, nelze vyloučit ani vliv národního přístupu. A to i přes výslovné zakotvení autonomního a mezinárodně jednotného přístupu uvedeného výslovně v článku 7.

Jak jsme již uvedli, Vídeňská úmluva neobsahuje výslovné připuštění či naopak vyloučení pravidla contra proferentem. Stanoviska, která se přiklánějí k aplikaci a podobě užití pravidla, uvádějí různé důvody pro. Jednu ze skupin názorů lze prezentovat na pozici P. Hubera. Ten uvádí, že samotná konstrukce a využití pravidel článku 8, zejména tedy odstavec 2 , vedou ve svém výsledku $\mathrm{k}$ obdobným účinkům, jaké má pravidlo contra proferentem. ${ }^{34}$ Podobné zaznívá z oblasti common law. ${ }^{35} \mathrm{Je}$ pravdou, že metodologicky není ztotožnění možného dosaženého výsledku při objektivním testu přijetím pravidla contra proferentem vzácné. Opět s odkazem na českou úpravu se objevuje analýza této možnosti i v české literatuře. ${ }^{36}$ Ona pozice osoby třetí s přihlédnutím ke všem okolnostem, které mají být vzaty do úvahy, zejména zde mezinárodního prostředí, nás může dovést u nejasného

31 K této části odkazujeme na zdařilou disputaci Kotáska na téma povahy pravidla ve vazbě k normativním výkladovým pravidlům včetně oné otázky, která stojí asi v centru aplikace: kdy toto pravidlo využít. Před, při či po, tedy tehdy, kdy vlastně ztroskotají jiná pravidla uváděná v normě. KOTÁSEK, Josef. Interpretace obchodních podmínek. In: BEJČEK, Josef, Josef KOTÁSEK, Monika PŘÍKAZSKÁ a kol. Obchodni podminky. Brno: Masarykova univerzita, Právnická fakulta, 2016, 304 s., s. 143-148. ISBN 978-80-210-8424-7.

$32 \mathrm{~K}$ ustanovení $\int 557 \mathrm{OZ}$, zakotvujícího zásadu contra proferentem resp. in dubio contra proferentem, viz včetně odkazu na judikaturu v české literatuře: KOTÁSEK, Josef. Interpretace obchodních podmínek. In: BEJČEK, Josef, Josef KOTÁSEK, Monika PŘÍKAZSKÁ a kol. Obchodni podminky. Brno: Masarykova univerzita, Právnická fakulta, 2016, 304 s., s. 139, dále také s. 143 a násl. ISBN 978-80-210-8424-7; Dále také PILÍK, Václav. Výklad právních jednání contra proferentem. Právní roz̧bledy, 2013, roč. 21, č. 6, s. $199-202$.

33 Digesta 2016, op. cit., s. 56, poznámka č. 46; Diskusi k případu BGH z 28. května 2014, VIII ZR 410/12 viz SCHROETER, Ulrich G. Rückkaufvereinbarungen und ,contra proferentem'-Regel unter dem UN-Kaufrecht (Repurchase Agreements and Interpretation, Contra Proferentem` under the UN Sales Convention (CISG). Internationales Handelsrecht, Köln: Verlag Dr. Otto Schmidt KG. 2014, roč. 16, s. 173-179.

34 HUBER, Peter. Some Introductory Remarks on the CISG. Internationales Handelsrecht. Munich: Sellier, European Law Publishers. 2006, roč. 18, č. 6, s. 237.

35 HONNOLD, J. Uniform Law for International Sales under the 1980 United Nations Convention. 3. vyd. The Hague: Kluwer Law International, 1999, 748 s., s. 117. ISBN 978-9041127532.

36 KOTÁSEK, Josef. Interpretace obchodních podmínek. In: BEJČEK, Josef, Josef KOTÁSEK, Monika PŘÍKAZSKÁ a kol. Obchodní podminky. Brno: Masarykova univerzita, Právnická fakulta, 2016, 304 s., s. 145. ISBN 978-80-210-8424-7. 
či problémového výrazu až k pozici, která je ve svém výsledku stejná. Nicméně se nedomníváme, že jde o prímé či mechanické využití či lze přímo v tomto ustanovení vidět promítnutí této zásady. ${ }^{37}$ Lze zde vidět souvislost, nikoli však přímou vazbu či ztotožnění.

Další skupina argumentů „pro“ použití je vyvozována spíše z obecných zásad, na nichž je úmluva založena. Variant může existovat více. Ostatně tak, jako není shoda ani na těchto výstavbových zásadách. Mưže jít o zásadu dělení rizik, která se i jinak projevuje $\mathrm{v}$ některých dalších ustanoveních Vídeňské úmluvy. ${ }^{38}$ Zásada contra proferentem z tohoto pohledu odpovídá smyslu této obecné zásady. Jinou variantou je využití dobré víry a z ní dovození výkladu. Další možná argumentace se opírá o lex mercatoria. Zejména vazba na soft dokumenty, výslovně připouštějící tuto zásadu, je lákavá. Mezi nimi samozřejmě sehrávají významnou roli Zásady mezinárodních smluv UNIDROIT, které výslovně uvádějí tuto zásadu. Nicméně jejich role jako obecného pravidla je diskutována a je sporná. ${ }^{39}$ Proti hovoří také ona skutečnost, že Vídeňská úmluva obsahuje výslovně pravidla výkladu, úprava se jeví být celistvá a zmínka o pravidle contra proferentem zde není. Podporu využití pravidla contra proferentem vyslovuje CISG Advisory Council Opinion No. 13. Inclusion of Standard Terms under the CISG (dále opinion No. 13), ${ }^{40}$ konkrétně jeho bod 9.41 Tento názor se výslovně váže ke standardizovaným podmínkám, tedy nikoli k plně individuálně sjednaným smlouvám. Uvádí, že v případě, kdy význam standardizovaného termínu poskytnutého jednou stranou zůstává dvojznačný navzdory provedené interpretaci, převáží význam, který je výhodnější pro druhou stranu (tedy jinou, než která př́slušný termín do podmínek uvedla). Toto stanovisko nesporně odpovídá situaci, kdy se jedná o obchodní podmínky navržené jednou stranou. Nicméně je to právě oblast

37 Jinak ovšem např́klad BGH v VIII ZR 410/12 ze dne 28. května 2014. Zdroj: UNILEX. Komentované př́pady k článku 8 [online]. [cit. 4.4.2018]. Dostupné z: http://www.unilex.info. Částečně kriticky k tomuto rozhodnutí SCHROETER, Ulrich G. Rückkaufvereinbarungen und 'contra proferentem'-Regel unter dem UN-Kaufrecht (Repurchase Agreements and Interpretation 'Contra Proferentem' under the UN Sales Convention (CISG). Internationales Handelsrecht, Köln: Verlag Dr. Otto Schmidt KG. 2014, roč. 16, s. 173-179; dále také výslovně v OLG Stuttgart 31. brę̧en 20086 U 220/07 [online]. [cit. 1.3. 2018]. Dostupné z: http://www.olg-stuttgart.de/pb/,Lde/Startseite/Entscheidungen

38 SCHMIDT-KESSEL, Martin. Art. 8. In: SCHLECHTRIEM, Peter a Ingeborg SCHWENZER. Kommentar zum Einheitlichen UN-Kaufrecht. 6. vyd. Munchen: Verlag C. H. Beck, 2013, 1444 s., s. 217. ISBN 978340664423 8; Jako o obecné zásadě hovoří i J. M. Lookofsky. LOOKOFSKY, M. J. Understanding the CISG. 3rd ed. Alphen aan den Rijn: Wolters Kluwer, 2008, 243 s., s. 162-165. ISBN 9789041125897.

39 K možnostem o využití Zásad mezinárodních smluv UNIDROIT jako obecných zásad viz v české literatuře na př́kladu doložky hardship: ROZEHNALOVÁ, Naděžda. Vyšší moc, hardship aneb smluvní doložky v mezinárodní praxi. Cáapis pro práuni védu a praxi [online]. 2015, č. 1, s. 64-65 [cit. 4. 5. 2018]. Dostupné z: https://journals.muni.cz/cpvp/article/view/5357. Ve světové literatuře např. BONELL, Joachim, M. The UNIDROIT Principles and CISG [online]. [cit. 2. 2. 2018]. Dostupné z: https://www.cisg. law.pace.edu/cisg/biblio/bonell.html

40 CISG Advisory Council Opinion No. 13. Inclusion of Standard Terms under the CISG [online]. [cit. 18. 1. 2018]. Dostupné z: http://www.cisg.law.pace.edu/cisg/CISG-AC-op13.html

41 „If the meaning of a standard term provided by one party remains ambiguous despite interpretation the meaning more favourable to the other party shall prevail." 
mezinárodního obchodu, která disponuje i podmínkami vytvářenými mimo dosah vůle konkrétních obchodníků. Např́klad pro oblast koupě-prodej podmínky GAFTA. ${ }^{42}$ Nebo podmínky zpracované i mezinárodními organizacemi jako je EHK OSN. Zde je navržené pravidlo obtížně obhájitelné. Zastáváme názor, že je vyloučeno právě pro povahu uvedených podmínek. Výklad takových podmínek bude odpovídat pravidlům uvedeným v odstavci 2 článku 8 a bude možné použít i výkladové metody známé spíše legislativním textům (kterým se v jistém ohledu přibližujî).

Jinou kontraktační variantou je sice využití obchodních podmínek - at' již vypracovaných nestátní organizací, nebo jednou stranou za situace jejich částečného přepracování a následného začlenění do smlouvy. Zde ono hledání významu tam, kde by byl pochybný, bude odvíjeno ad hoc at' již na úrovni odstavce prvého či na úrovni odstavce druhého. Rovněž ani zde nevidíme prostor pro pozici contra proferentem.

Lze uzavřít, že existuje obecný př́klon $\mathrm{k}$ využití zásady contra proferentem i při aplikaci Vídeňské úmluvy. Při jejím využití ovšem vidíme logické limity dané jak konkrétní situací, tak i povahou kontraktace. Zásada by měla být využita teprve poté, kdy ,ztroskotají snahy o výklad dle pravidel uvedených v článku 8 a význam termínu zůstává nejasný. Zásada contra proferentem není zařazena do oné interpretační hierarchie tak, jak je tomu u subjektivního a objektivního přístupu. A nemůže je ani nahradit. Není, a to na rozdíl od některých vnitrostátních úprav, výslovně prripuštěna. Nicméně v konkrétním případě lze toto pravidlo využít. Podmínkou využití pravidla je existence pochybnosti o významu prohlášení, textu atd. Nikoli však neexistence. Ono druhé nás již vede k problematice vyplnění mezer smlouvy - ta ovšem disponuje jinými pravidly. I když v konkrétním př́ípadě je hranice mezi nimi křehká a závisí na umu aplikujícího orgánu, jak se vypořádá s uchopením institutů. Rovněž by nemělo dojít - při nenalezení řešení dle odst. 1 ke ztotožnění, resp. automatickému promítnutí pravidla contra proferentem do odstavce druhého - pozice rozumné osoby v tomtéž postavení jako druhá strana.

Dalším z pravidel, které není výslovně uvedeno v článku 8 Vídeňské úmluvy, nicméně diskuse o jeho využití se objevuje jak v literatuře, tak i v rozhodnutích soudů, je přihlédnutí k zásadě dobré víry. ${ }^{43}$ Samotné uchopení dobré víry osciluje mezi morálním imperativem, přirozeně obsaženém jako prvek jakéhokoli jednání stran, a právním principem.

Dobrá víra je v úmluvě uchopena výslovně jako interpretační kritérium v článku 7 odst. 1 pro text Vídeňské úmluvy. Dle řady názorů se jedná také o obecný princip,

42 GAFTA - Grain and Feed Trade Association. Na jejích www lze dohledat řadu standardizovaných podmínek, resp. zde spíše i formulářových smluv pro obchod s obilím a krmivy. Dostupné z: https://www. gafta.com/All-Contracts

43 MAGNUS, Ulrich. Remarks on Good Faith: The United Nation Convention on Contracts for the International Sale of Goods and the International Institute for the Unification of Private Law, Principles of International Commercial Contracts. Pace International Law Review, 1998, roč. 10, č. 1, s. 93; Digesta 2012 - př̀klad, op. cit., s. 56. 
zásadu, na které je sama úmluva postavena a kterou lze nalézt v řadě jejích ustanovení. ${ }^{44}$ Od těchto dvou pozic je nutné odlišit její „uchopeni““v rámci národního práva, kde hraje rovněž různou roli (viz např́lklad zásadu Treu und Glauben v německém právu).$^{45} \mathrm{~V}$ některých zemích je „dobrá víra“ principem limitovaným na plnění smlouvy (některé země anglosaské či např́klad Francie), v jiných zemích jde o princip vážící se také k interpretaci smlouvy či k utváření smlouvy.

„Dodáni““ onoho třetího kritéria do ustanovení o interpretačních zásadách platných pro text samotné Vídeňské úmluvy bylo jistým kompromisem mezi delegacemi zastávajícími názor o obecném uvedení principu dobré víry minimálně pro fázi uzavírání smlouvy a těmi, kteří ji odmítli pro zavedení prvků nejistoty. V materiálu, který byl vypracován pro aplikaci Vídeňské úmluvy v anglosaských zemích, je zdůrazněna i další role zásady - a to poměrně zajímavá právě pro námi sledovaný účel. Dobrá víra jako interpretační zásada dává soudům prostor, flexibilitu, která je nutná pro použití textu v praxi. Tato flexibilita dovoluje rozhodujícímu orgánu překonat jazykovou interpretaci textu, která by mohla vést k výsledkům nezamýšleným navrhovateli. Rovněž může napomoci tomu, aby se rozhodující orgán prúliš rychle neuchyloval k domácímu právu. Dále je zdůrazněno, že závazek jednání v dobré víře mưže posílit vztahy mezi podnikateli. ${ }^{46}$

Argumentace „pro“ využití principu dobré víry jako interpretačního kritéria i pro jednání stran, a to at' již v rámci subjektivního testu, či testu objektivního, může vycházet z vícera pozic. Nesporně silný je onen morální apel včetně právního uchopení obecných principů. Nicméně nikoli nezajímavý je pohled metodologický. Je-li tato zásada nesporně zásadou ovládající interpretaci textu úmluvy, resp. jejich jednotlivých článků, je nutně také zásadou ovládající interpretační uchopení článku 8 a promítající se i do regulace chování, prohlášení atd. stran. Vyloučit nelze ani vliv vůle stran s využitím článku 6. Na mysli tím máme ona různá obecná prohlášení ve smlouvě, obvykle zakotvená v úvodní preambuli či článku, kde strany prohlašují a zavazují se jednat v souladu s dobrou vírou a pravidly poctivého obchodního styku.

Dle našeho názoru lze stěží nalézt argumenty pro pozici nepřihlédnutí k principu dobré víry. S výjimkou argumentů formálních opírajících se o samotný text Úmluvy a její zařazení do článku $7 .^{47}$

44 Digesta 2012 - překlad, op. cit., s. 43.

45 FERRARI, Franco. Art. 7. In: SCHLECHTRIEM, Peter a Ingeborg SCHWENZER. Kommentar zum Einbeitlichen UN-Kaufrecht. 6. vyd. Munchen: Verlag C. H. Beck, 2013, 1444 s., s. 171. ISBN 978340664423 8; NOVÝ, Zdeněk. Dobrá víra jako princip smluwního práva v męinárodním obchodu. 1. vyd. Praha: C. H. Beck, 232 s., s. 37-82. ISBN 978-80-7400-376-9.

46 Documents, op. cit., s. 11.

47 BELL, Gary F. How the Fact of the Accepting Good Faith as the General Principle of the CISG will bring more Uniformity. Review of the Convention on Contracts for the International Sale of Goods (CISG) 2005-2006. 1. vyd. Munich: Sellier. European Law Publishers, 2007, 260 s., s. 8-20. ISBN 978-3-86653-016-4. 


\section{K některým frekventovaným doložkám pohledem Vídeňské úmluvy}

Mezinárodní obchodní praxe, vytvořená na průsečíku rưzných právních kultur a ovlivněná i obchodovanými komoditami a výrobky, využívá pravidelně smluvní klauzule, které mohou napomoci interpretaci jednání či prohlášení. Samozřejmě, pokud neznáme jejich význam, resp. nakolik je jim v různých oblastech přiznáván odlišný smysl, může být jejich využití kontraproduktivní. Pro nás je zajímavá otázka, nakolik jsou tyto doložky slučitelné s Vídeňskou úmluvou a jejími principy. Jde o doložky, které nejsou př́mo upraveny v ustanoveních úmluvy. Je však otázkou, zda je lze vyvodit ze základních principů, jimiž je úmluva ovládána. Nebo zda lze s jistou mírou jistoty dovodit možnost či nemožnost jejich využití. Využití doložek známých jako tzv. merger clause (resp. entire agreement clause, four corner clause, zip clause, integration clause, intégralité de convention, clause d'accord complet, Integrationsklausel, Vollständigkeitskelauseb) ${ }^{48}$ je v právní praxi významné. ${ }^{49}$ Jejich cílem je vyloučit pro interpretaci smlouvy ujednání, prohlášení, dokumentaci atd., které ředcházejí písemné smlouvě, vyjma ní samotné. Tedy jednoduše řečeno vyčištění prostředí od možných aktů učiněných v rámci kontraktace tam, kde byl jejich význam v čase překonán. Nicméně v následném sporu by jich mohlo být druhou stranou využito jako důkazu pro vysvětlení jiného významu prohlášení.

Z jiného pohledu než interpretačního lze vnímat tyto doložky jako snahu o vyjádření komplexnosti smlouvy jako písemného dokumentu.

Význam této doložky je značný tam, kde jsou vedena delší a složitá kontraktační jednání a mezi stranami je vyměněna řada dokumentů. Nebo dochází k následným změnám smlouvy. V souladu s CISG Advisory Council Opinion No. 3. Parol Evidence Rule, Plain Meaning Rule, Contractual Merger Clause and the CISG $^{50}$ (dále jen opinion No. 3) je tato doložka

$48 \mathrm{~V}$ české literatuře $\mathrm{k}$ dané problematice a uvedení různých podob doložek především KOTÁSEK, Josef. Doložka úplnosti a její limity. Pránni rožbledy, Praha: Nakladatelství C. H. Beck, 2016, roč. 24, č. 21, s. 725-732. Uvádí dále i - dle jeho slov - sofistikovanější podobu těchto „čistících doložek“ tzv. non reliance clause. A zejména upozorňuje na různé varianty doložek - sahajících od smluvních modifikací až k významu pro interpretaci. Což je naše pozice zde.

49 Nikoli náhodou jsou uvedeny v PECL Principles of European Contract Law v čl. 2: 105; v Zásadách UNIDROIT The Principles of International Commercial Contracts v čl. 2. 1. 17. PECL i další evropský dokument DCFR (Draft Common Frame of Reference) v čl. II.-4:104. PECL i DCFR omezují dopad na individuálně ujednané smlouvy.

Při využití obchodních podmínek omezuji dopad doložky jen na vyvratitelnou domněnku. Navíc tam, kde byly předkontraktační dokumenty, prohlášení atd. využity jako nástroj interpretace, nelze je vyvrátit. K tomu všemu je výslovně v obou dokumentech zakotven princip venire contra factum proprium. V literature viz: PINKEL, Tobias. The Effect of Merger and Non-Reliance Clauses according the Art. 72 of the Commision's Draft of the Common European Sales Law (CESL) - a Model for New Instrument International or European Instrument for (Consumers) Sales Law. In: Aurelia Colombi CIACCHI, Aurelia Colombi. Contents and Effects of Contracts-Lessons to Learn From The Common European Sales Law. Springer International Publishing, 2016, 295 s., s. 216. ISBN 978-3-319-28072-1.

50 CISG Advisory Council Opinion No. 3. Parol Evidence Rule, Plain Meaning Rule, Contractual Merger Clause and the CISG. [online]. [cit. 5. 2. 2018], v textu dále "Opinion No. 3". Dostupné z: http://www.cisgac.com/ 
tam, kde je smlouva podř́zena Vídeňské úmluvě, př́ípustná a může mít za účinek vyloučení uvedených písemností předcházejících uzavřenou smlouvu pro její interpretaci. Může zabránit, při vyhodnocení všech ostatních faktorů, odvolání se na takové důkazy. ${ }^{51}$ Nicméně je zdůrazněno, že uvedené vyloučení zohlednění musí být skutečně stranami zamýšleno. Právě článek 8 Vídeňské úmluvy vyžaduje přezkoumání všech relevantních skutečností a okolností pro to, abychom se rozhodli, zda taková doložka reprezentuje záměr stran. Využití uvedené doložky navazuje na možnosti dané článkem 6 Vídeňské úmluvy a princip autonomie vůle stran.

Naopak, v souladu s uvedeným názorem v opinion No. 3, je vyloučeno využití tzv. plain meaning rule jako pravidla či doktríny, která se objevuje také $\mathrm{v}$ rámci některých common law jurisdikcí. Uvedené pravidlo předpokládá tam, kde je prostý význam termínu jazykově zcela jasný, nepoužít jiné dodatečné prostředky jako jsou např́klad jednání o smlouvě apod. k objasnění významu. Uvedená doložka by byla - v souladu s převažujícími názory $-\mathrm{v}$ prímém rozporu s článkem 8 odst. 3. Zde by potom bylo nutné uvažovat o tom, zda daná kapitola, v níž se nachází článek 8, je vylučitelná článkem 6 . Tedy vytvořní situace, kdy by bylo možné přijmout výslovně ve smlouvě zcela jiná pravidla pro její interpretaci než jsou ta, která jsou uvedena v části I Vídeňské úmluvy.

V souladu s uvedeným názorem v opinion No. 3 je vyloučeno ve smlouvách, na které dopadá Vídeňská úmluva, využití parol evidence rule. Ustanovení článku 8 totiž výslovně upravuje pozici, kterou dává písemnému textu smlouvy. Parol evidence rule jako pravidlo, které je rozšířeno v oblastech common law, umožňuje soudci zabránit v prrípadě psaných smluv zohlednění ústních ujednání či dokumentace předcházející smlouvu, které by měnily význam písemného textu smlouvy či ji anulovalo, s výjimkou případu podvodu či chyby. Umožňuje mu vyloučit z důkazů právě tyto typy důkazů (výslovně ,extrinsic and parol evidence ").

\section{Zvláštnosti včlenění obchodních podmínek z pohledu článku 8}

Další z otázek, která se váže částí svých problémů k článku 8, je problematika včlenění standardizovaných podmínek. Vídeňská úmluva neobsahuje speciální pravidlo týkající se včlenění těchto podmínek. Pokud jde o rozhraničení působnosti národního práva a Vídeňské úmluvy, zdá se, že převažuje názor, že otázka, zda byly standardní podmínky platně včleněny do smlouvy, je otázkou, která má být řešena pohledem kontraktačního

51 V již citovaném článku J. Kotáska je uveden i odkaz na možnosti článku 29 Vídeňské úmluvy ve vazbě na uvedenou doložku. Autor uvádí pohled uvedený v článku Viscasillase (PERALES VISCASILLAS, P. M. Modification and Termination of Contracts (Art. 29 CISG). Dostupné z: https://www.uncitral.org/ pdf/english/CISG25/Viscasillas.pdf [cit. 2.8.2018]). Ten s odkazem na rozhodčí nález MOK v Paříži č. 9117/1998 uvádí jako možnost i využití článku 29 odst. 2. Tento názor nesdílíme. V tomto článku Vídeňské úmluvy je třeba vidět spíše promítnutí zásady estoppel či venire contra factum proprium. KOTÁSEK, Josef. Doložka úplnosti a její limity. Právní roz̧hledy, Praha: Nakladatelství C. H. Beck, 2016, roč. 24 , č. 21 , s. $725-732$. 
procesu upraveného ve Vídeňské úmluvě a kritérii uvedenými článku 8, tj. interpretací vůle stran. Nikoli národním právem. Naopak otázka jejího obsahu, tzv. materiální platnost, je otázkou vyloučenou čl. 4 a spadající do dosahu národního práva. ${ }^{52}$

Ve stejném duchu vyznívá i CISG opinion No. 13. Názor v prvé radě zdůrazňuje to, že včlenění standardizovaných podmínek dle Vídeňské úmluvy je řešeno v souladu s normami týkajícími se utváření a interpretace smlouvy, či spíše jednotlivých úkonů stran jako je nabídka a její přijetí. Zvážit je ovšem nutné také využití článku 9, kdy mưže vzniknout mezi stranami jistá praxe, z jejíhož pohledu je třeba prohlášení či chování strany interpretovat. Anebo dokonce by mohla v dané komunitě obchodníků existovat i mezinárodní obchodní zvyklost. Vedle dalších otázek je třeba pro využití článku 8 zmínit i pravidlo číslo 6. Dle něj je včlenění považováno za jasné tam, kde naprríklad jsou podmínky čitelné a může jim porozumět rozumná osoba. Rovněž je výslovně upraven požadavek na jazyk - mají být dostupné v jazyce, od něhož lze očekávat, že mu rozumná osoba porozumí. Takovým může být jazyk smlouvy, jazyk jednání či jazyk stranou pravidelně používaný.

Zde je poměrně zajímavá i praxe soudů. Digesta uvádějí několik případů, kdy soudy rozhodly o tom, že podmínky nejsou součástí smlouvy. Např́iklad v situaci, kdy byly podmínky psány v jiném jazyce než smlouva a strana, která je navrhla, nedala druhé straně k dispozici překlad, soud uvedl, že tyto podmínky se nestaly součástí smlouvy. Oproti tomu stojí naopak rozhodnutí, ve kterém bylo zdůrazněno, že pouhý fakt rozdílného jazyka neznamená neplatnost včlenění. Jak uvádí s ohledem na tento přehled v Digestech Ferrari, omezenost významu Digest, které nehodnotí rozdílnost v rozhodování, značně snižuje jejich význam. ${ }^{53}$.

\section{Závěr}

Ani výslovná regulace interpretace jednání, prohlášení atd. strany tak, jak se nám jeví v článku 8 Vídeňské úmluvy, nedává jednoznačnou odpověd’ na řadu otázek, které jsou navázány na pohyb smlouvy $\mathrm{v}$ mezinárodním prostředí. V konkrétním případě je nutné dbát na jasné formulace a nespoléhat na řešení, která jsou přijímána na národní půdě. A současně je nutné počítat s tím, že nelze najít jediné řešení - vždy záleží na ad hoc hodnocení. V mezinárodním prostředí je nutné vnímat také dopad tzv. nestátních prostředků typu INCOTERMS či tzv. interpretační zvyklosti. Ty jsou schopny posunout význam určitého termínu oproti obecnému vnímání termínu.

52 HUBER, Peter a Alastair MULLIS. The CISG: A New Textbook for Students and Practitioners. Sellier. European Law Publishers. 2007, 408 s., s. 30. ISBN 978-3-86653-020-1; Digesta 2016, op. cit., s. 57.

53 FERRARI, Franco, Harry FLECHTNER a Ronald A. BRAND (eds.). The Draft UNCITRAL Digest and Beyond. 1. vyd. Munich: Sellier. European Law Publishers, 2004, 874 s., s. 190. ISBN 3-935808-14-3. Digesta 2016, op. cit., s. 57. 